(RESEARCH ARTICLE)

\title{
Growth and yield response of streak virus resistant maize (TZESR-W) to different nitrogen rates on a sandy loam soil of semi-arid region of Nigeria
}

\author{
Kaltungo Joseph Hussaini $1{ }^{1}{ }^{*}$, Voncir Nanmwa ${ }^{2}$ and Singh Lallan ${ }^{3}$ \\ ${ }^{1}$ Department of Technical Services, Gombe State Agricultural Development Programme, Gombe Nigeria. \\ ${ }^{2}$ Soil Science Department, Faculty of Agriculture and Agricultural Technology, Abubakar Tafawa Balewa University \\ Bauchi, Nigeria. \\ ${ }^{3}$ Soil Science Department, Moddibo Adama University of Technology, Yola, Nigeria.
}

Publication history: Received on 27 January 2020; revised on 11 February 2020; accepted on 13 February 2020

Article DOI: https://doi.org/10.30574/wjarr.2020.5.2.0026

\begin{abstract}
Field experiments were conducted at Abubakar Tafawa Balewa University Research Farm, Bauchi during the 1992 and 1993 cropping seasons to investigate the "Growth and yield response of streak virus resistant maize (TZESR-W) to different $\mathrm{N}$ rates on a sandy loam soil of semi-arid region of Nigeria". Experimental treatments consisted of seven rates of $\mathrm{N}(0,50,100,150,200,250$ and $300 \mathrm{KgN} / \mathrm{ha})$ and optimum levels of $\mathrm{P}(17.5 \mathrm{Kg} / \mathrm{ha})$ and $\mathrm{K}(50 \mathrm{Kg} / \mathrm{ha})$ applied as base rates. These were tested in a randomized complete block design with 3 replications. $\mathrm{N}$ was split applied by side dressing in two equal does: half at two weeks after sowing and the other half at 5 weeks after sowing. Experimental results revealed that the application of $\mathrm{N}$ fertilizer up to $100 \mathrm{KgN} / \mathrm{ha}$ significantly increased the maize plant height, number of cobs, cob length, cob girth, cob weight, grain yield, stover yield and percent $\mathrm{N}$ in grain and stover over the absolute control in both 1992 and 1993 cropping seasons. In other words, the application of $\mathrm{N}$ fertilizer beyond $100 \mathrm{KgN} /$ ha was not significant when compared with the absolute control. On the other hand, shelling percentage, 1000-grain weight and $\mathrm{N}$ uptake by stover were not significantly affected by $\mathrm{N}$ fertilizer application. This study therefore suggested that maize (TZESR-W) could be grown on a sandy loam soil of semi-arid region of Nigeria with the application of $100 \mathrm{KgN} / \mathrm{ha}, 17.5 \mathrm{KgP} / \mathrm{ha}$ and $50 \mathrm{KgK} / \mathrm{ha}$. Application of N fertilizer beyond $100 \mathrm{KgN} / \mathrm{ha}$ on TZESR-W is a waste of resources.
\end{abstract}

Keywords: Maize; Nitrogen; Soil; Arid

\section{Introduction}

Nitrogen is one of the main limiting factors of maize production in the savanna zones of Nigeria. Normally, maize do well on deep, well drained loamy soils which are rich in organic matter and nitrogen. Effect of $\mathrm{N}$ during vegetative growth appears to be more pronounced on maize stalk and final plant height is normally reduced in the absence of $\mathrm{N}$. [1] (Kaltungo, 1995). [2] Balasubramanian et al, (1978) observed that maize crop failed to produce worthwhile grain in the absence of $\mathrm{N}$ fertilization in Samaru, Nigeria. They also observed that maize is a potentially high yielding crop especially under optimum management conditions; its demand for $\mathrm{N}$ is therefore higher than other cereals.

Work on nitrogen fertilization of maize carried out in the past indicated that maize cultivation in the savanna zones of Nigeria requires the application of $120 \mathrm{KgN} /$ ha to $150 \mathrm{KgN} / \mathrm{ha}$ [3] (Olugunde 1981) but with the development of new early maturing varieties especially streak virus resistant, it has become pertinent to work out agronomic and nutritional requirements of maize in the savanna zone of Nigeria. In view of the above, the present study was undertaken as a first step to work out the $\mathrm{N}$ requirement of new streak virus resistant variety of maize under optimum level of applied P and K [1].

\footnotetext{
${ }^{*}$ Corresponding author

E-mail address: jhkaltungo@yahoo.com
} 


\section{Material and methods}

Field experiments were conducted during the 1992 and 1993 raining seasons (June to October) at Abubakar Tafawa Balewa University Research Farm at Bauchi, Nigeria. There were 7 levels of N (0, 50,100,150,200,250 and 300 $\mathrm{KgN} / \mathrm{ha}$ ) and an absolute control plot arranged in a randomized complete block design with 3 replications.

After ploughing and harrowing, the field was marked out into plots of $26.25 \mathrm{~m}^{2}(5.25 \mathrm{mx} 5.0 \mathrm{~m})$ each. Before harrowing the field, a uniform does of $\mathrm{P}$ and $\mathrm{K}$ at the rate of $17.5 \mathrm{KgP}$ and $50 \mathrm{KgK} / \mathrm{ha}$ respectively were applied to all the plots with the exception of the absolute control plots. Maize variety TZESR-W (an improved white maize variety) was sown on $10^{\text {th }}$ and $2^{\text {nd }}$ July in 1992 and 1993 wet seasons respectively following a row to row and plant to plant spacing of $75 \mathrm{~cm}$ and $25 \mathrm{~cm}$ respectively. No cropping activity was done in between the two maize seasons.

Nitrogen through urea was applied in two equal split doses: one at 2 weeks after sowing and the second at 5 weeks after sowing as side dressing. Normal weeding and hoeing were carried out manually to keep the field free of weeds.

Before applying fertilizer, composite soil samples at $0-15 \mathrm{~cm}$ and $15-30 \mathrm{~cm}$ depths were collected randomly from the experimental fields in both 1992 and 1993 to find out the initial soil test values. Soil samples so collected were analyzed for physico-chemical properties following the conventional methods of soil analysis.

Data on plant growth such as plant height was taken at different intervals [35, 65 and 102 days after sowing (DAS)] and increase in plant height per day was calculated.

Yield data and other characteristics such as cob length, cob girth, cob weight, shelling percentage and 1000-grain weight were measured and calculated from the samples taken from the net harvested area of $12 \mathrm{~m}^{2}$. Cob length and cob girth were measured using venire calipers. Shelling $\%$ was calculated by dividing the grain weight by cob weight and the product is multiplied by 100.

Grain and stover yields were calculated and recorded from the net plot harvested for each treatment. Samples of grain and stover were taken in 1993 only for the analysis of $\mathrm{N}$ and $\mathrm{N}$ uptake. Nitrogen in grain and stover was determined using microkjeldahl distillation procedure.

\section{Results and discussion}

\subsection{Soil characteristics}

Table 1 Physico-chemical Properties of the Soils of the Experimental site during 1992 and 1993 Cropping seasons at Bauchi, Nigeria.

\begin{tabular}{lccccc}
\hline \multirow{2}{*}{ Soil Parameters } & \multicolumn{2}{c}{$\mathbf{1 9 9 2}$} & \multicolumn{2}{c}{$\mathbf{1 9 9 3}$} \\
& \multicolumn{2}{c}{ Soil Depth (cm) } & \multicolumn{2}{c}{ Soil Depth (cm) } \\
& $\mathbf{0 - 1 5}$ & $\mathbf{1 5 - 3 0}$ & $\mathbf{0 - 1 5}$ & $\mathbf{1 5 - 3 0}$ \\
\hline Mechanical Analysis & & & & \\
Sand (\%) & 74 & 71 & 67 & 65 \\
Silt (\%) & 11 & 12 & 14 & 16 \\
Clay (\%) & 15 & 17 & 19 & 19 \\
\hline Textural class & \multicolumn{1}{c}{ Sandy } & -Loam & \multicolumn{2}{c}{ Sandy } & -Loam \\
\hline Chemical analysis & & & & \\
PH(1:1 Soil: water suspension) & 6.0 & 6.30 & 6.72 & 6.19 \\
Organic Carbon(\%) & 0.68 & 0.24 & 0.54 & 0.40 \\
Total-N(\%) & 0.053 & 0.035 & 0.099 & 0.088 \\
C/N ration & 12.83 & 6.85 & 5.46 & 4.55 \\
Available-P(ppm)(Bray-1 & 4.51 & 4.53 & 9.15 & 9.03 \\
Exchangeable cations(meq/100g) & & & & \\
Ca & 3.49 & 4.15 & 3.19 & 3.76 \\
Mg & 0.93 & 1.17 & 0.95 & 1.05 \\
K & 0.24 & 0.19 & 0.21 & 0.15 \\
Na & 0.11 & 0.18 & 0.15 & 0.13 \\
CEC(Meq/100g) & 4.77 & 5.69 & 4.50 & 5.09 \\
\hline
\end{tabular}


Soil of the experimental site is sandy loam in texture with no marked differences in sand, silt and clay content in between 0-15 and 15-30 cm depths (Table 1). Soil reaction $(\mathrm{pH})$ is 7.2 with low organic carbon and total nitrogen content. Available P during 1992 season was lower than in 1993. Relatively high level of available P in the experimental plot of 1993 (Table1) is primarily due to the high levels of P fertilization from soybean crop previously grown in the area. Cation exchange capacity of the soil is low; the dominant Cation in both the soil depths is calcium (Table1).

\subsection{Plant Height}

Plant Height as influenced by $\mathrm{N}$ fertilizer application is presented in Table 2. The result indicated that plant height of maize was significantly affected by $\mathrm{N}$ fertilizer application at all stages of sampling (35, 63 and 102 days after sowing) when compared with the absolute control in both 1992 and 1993 seasons. Moreover, the result showed that the application of $\mathrm{N}$ fertilizer up to $100 \mathrm{KgN} /$ ha with $17.5 \mathrm{KgP} /$ ha and $50 \mathrm{KgK} /$ ha resulted in taller plants when compared with the absolute control. It was also observed that plant heights of the maize plant increased with the age of the plant, as plant height at 102 DAS was taller than at 63 DAS. Similarly, plant height at 63 DAS was taller than plant height at 35 DAS.

The study went further to calculate increased in plant height per day. Thus, it was observed that increase in plant height per day as influenced by $\mathrm{N}$ fertilizer application, was more pronounced between 35 and 63 DAS and low between 63 and 102 DAS. This observation indicated that vegetative growth was maximum up to 63 DAS and later on it slowed down and nutrients absorbed were utilized for reproductive phase of development. Results obtained by [4]El-Sharkaway et al, (1976) and [5] Adetiloye et al, (1984) indicated that plant heights consistently reduced in the absence of applied $\mathrm{N}$ and that $\mathrm{N}$ is required mostly in the early part of the plant life cycle.

Table 2 Effects of $\mathrm{N}$ on Plant Height $(\mathrm{cm})$ and increase in Plant Height per day $(\mathrm{cm})$ at various stages of Maize Growth during 1992 and 1993 Cropping Seasons

\begin{tabular}{|c|c|c|c|c|c|c|}
\hline \multirow{2}{*}{$\begin{array}{l}\text { Treatment } \\
\text { (Kg/ha) }\end{array}$} & \multicolumn{3}{|c|}{ Plant Height(cm) 1992} & \multicolumn{3}{|c|}{ Plant Height(cm) 1993} \\
\hline & 35 DAS & \multicolumn{3}{|c|}{ (Harvest) } & \multicolumn{2}{|c|}{ (Harvest) } \\
\hline $\begin{array}{l}\mathrm{T}_{0} \text {-Absolute Control } \\
\text { (no N,P and } \mathrm{K} \text { ) }\end{array}$ & $\begin{array}{l}0.63 \\
(1.80)\end{array}$ & 1.69 & 1.72 & $\begin{array}{c}0.40 \\
(1.14)\end{array}$ & 1.19 & 1.83 \\
\hline $\begin{array}{l}\mathrm{T}_{1} \text { - Control } \\
\text { (only } \mathrm{P} \text { and } \mathrm{K} \text { ) }\end{array}$ & $\begin{array}{l}0.68 \\
(1.94)\end{array}$ & 1.95 & 2.21 & $\begin{array}{c}0.51 \\
(1.46)\end{array}$ & 1.39 & 2.09 \\
\hline $\mathrm{T}_{2}-\mathrm{N}_{50}+\mathrm{T}_{1}$ & $\begin{array}{l}0.82 \\
(2.34)\end{array}$ & 2.20 & 2.56 & $\begin{array}{c}0.65 \\
(1.86)\end{array}$ & 2.03 & 2.60 \\
\hline $\mathrm{T}_{3}-\mathrm{N}_{100}+\mathrm{T}_{1}$ & $\begin{array}{l}0.84 \\
(2.40)\end{array}$ & 2.35 & 2.75 & $\begin{array}{l}0.79 \\
(2.26)\end{array}$ & 2.13 & 2.88 \\
\hline $\mathrm{T}_{4}-\mathrm{N}_{150}+\mathrm{T}_{1}$ & $\begin{array}{l}0.81 \\
(2.31)\end{array}$ & 2.09 & 2.51 & $\begin{array}{c}0.72 \\
(2.06)\end{array}$ & 1.94 & 2.53 \\
\hline $\mathrm{T}_{5}-\mathrm{N}_{200}+\mathrm{T}_{1}$ & $\begin{array}{l}0.83 \\
(2.37)\end{array}$ & 2.34 & 2.60 & $\begin{array}{l}0.74 \\
(2.11)\end{array}$ & 1.98 & 2.49 \\
\hline $\mathrm{T}_{6}-\mathrm{N}_{250}+\mathrm{T}_{1}$ & $\begin{array}{l}0.88 \\
(2.51)\end{array}$ & 2.47 & 2.56 & $\begin{array}{l}0.79 \\
(2.26)\end{array}$ & 1.96 & 2.50 \\
\hline $\mathrm{T}_{7}-\mathrm{N}_{300}+\mathrm{T}_{1}$ & $\begin{array}{l}0.86 \\
(2.41)\end{array}$ & 2.42 & 2.50 & $\begin{array}{l}0.80 \\
(2.29)\end{array}$ & 1.92 & 2.61 \\
\hline SE & 0.06 & 0.13 & 0.11 & 0.15 & 0.14 & 0.13 \\
\hline $\operatorname{LSD}(0.05)$ & 0.18 & 0.36 & 0.32 & 0.43 & 0.39 & 0.37 \\
\hline
\end{tabular}

Figures in parenthesis are increase in height in cm per day 


\subsection{Cob Length and Cob Girth}

Data on cob length and cob girth of maize is presented in Table 3. The data indicated that cob length and cob girth of maize was significantly increased with the application of $\mathrm{N}$ fertilizers over the absolute control. The result also indicated that the application of $\mathrm{N}$ fertilizer up to $100 \mathrm{KgN} / \mathrm{ha}$ significantly increased the length and girth of maize in 1992; beyond this level, the increase was not significant.[6] Nimje and Seth (1988) and [7] Bataev et al, (1991) had earlier reported increase in cob size with the application of $\mathrm{N}$ levels.

Table 3 Effect of N on Cob Length and Cob Girth during 1992 and 1993 Cropping Seasons

\begin{tabular}{lcccc}
\hline $\begin{array}{l}\text { Treatment } \\
\text { (Kg/ha) }\end{array}$ & \multicolumn{2}{c}{ Mean Cob Length(cm) } & \multicolumn{2}{c}{ Mean Cob Girth(cm) } \\
& $\mathbf{1 9 9 2}$ & $\mathbf{1 9 9 3}$ & $\mathbf{1 9 9 2}$ & $\mathbf{1 9 9 3}$ \\
\hline $\begin{array}{l}\text { To-Absolute Control } \\
\text { (no N,P and K) }\end{array}$ & 10.8 & 8.7 & 10.6 & 8.9 \\
& & & & \\
T1-Control & 12.8 & 9.3 & 12.9 & 7.9 \\
(only P and K) & & & & \\
& & & 13.9 & 12.9 \\
T2-N50+T1 & 14.7 & 14.4 & 14.6 & 12.3 \\
T3-N100+T1 & 16.7 & 12.6 & 13.9 & 11.9 \\
T4-N150+T1 & 15.4 & 12.2 & 13.6 & 11.6 \\
T5-N200+T1 & 16.1 & 11.9 & 14.6 & 13.0 \\
T6-N250+T1 & 17.1 & 14.3 & 14.4 & 12.5 \\
T7-N300+T1 & 16.5 & 14.5 & 0.59 & 1.41 \\
SE & 0.74 & 1.41 & 1.60 & 4.10 \\
LSD(0.05) & 2.05 & 4.00 & & \\
\hline & \multicolumn{5}{c}{$\mathrm{T}_{1}=17.5 \mathrm{KgP}+50 \mathrm{KgK} / \mathrm{ha}$} \\
\end{tabular}

\subsection{Cob Weight, Shelling Percentage and 1000-grain weight}

Table 4 is data on cob weight, shelling percentage and 1000-grain weight of maize in 1992 and 1993 . The data indicated that the application of $\mathrm{N}$ fertilizer up to $100 \mathrm{kgN} / \mathrm{ha}$ significantly increased the cob weight of maize (TZESRW) when compared with the no $\mathrm{N}$ control. The application of $\mathrm{N}$ beyond $100 \mathrm{kgN} / \mathrm{ha}$ on cob weight was not significant. The earlier study of [4] El-Sharkaway et al, (1976) and [8] Gagro (1977) revealed that application of N beyond 150 $\mathrm{KgN} / \mathrm{ha}$ will not increase cob weight significantly.

Table 4 Effect of N on Cob Weight, Shelling Percentage and 1000-Grain Weight during 1992 and 1993 Cropping Seasons.

\begin{tabular}{|c|c|c|c|c|c|c|}
\hline \multirow[t]{2}{*}{$\begin{array}{l}\text { Treatment } \\
\text { (Kg/ha) }\end{array}$} & \multicolumn{2}{|c|}{$\begin{array}{l}\text { Cob Weight } \\
\text { (Kg/ha) }\end{array}$} & \multicolumn{2}{|c|}{$\begin{array}{l}\text { Shelling } \\
\text { Percent (\%) }\end{array}$} & \multicolumn{2}{|c|}{$\begin{array}{c}\text { 1000-Grain Weight } \\
\text { (g) }\end{array}$} \\
\hline & 1992 & 1993 & 1992 & 1993 & 1992 & 1993 \\
\hline $\begin{array}{l}\text { To-Absolute Control } \\
\text { (no N,P and K) }\end{array}$ & 1667 & 1667 & 87.7 & 73.2 & 138.7 & 173.8 \\
\hline $\begin{array}{l}\text { T1-Control } \\
\text { (only P and K) }\end{array}$ & 1833 & 1916 & 79.2 & 68.2 & 211.6 & 193.8 \\
\hline $\begin{array}{l}\text { T2-N50+T1 } \\
\text { T3-N100+T1 }\end{array}$ & $\begin{array}{l}2750 \\
4667\end{array}$ & $\begin{array}{l}3250 \\
4833\end{array}$ & $\begin{array}{l}87.5 \\
79.1\end{array}$ & $\begin{array}{l}208.9 \\
73.6\end{array}$ & $\begin{array}{l}208.9 \\
222.4\end{array}$ & $\begin{array}{l}193.9 \\
206.8\end{array}$ \\
\hline T4-N150+T1 & 4250 & 4750 & 87.2 & 68.2 & 212.9 & 109.7 \\
\hline $\mathrm{T} 5-\mathrm{N} 200+\mathrm{T} 1$ & 5767 & 4417 & 801.1 & 65.0 & 234.4 & 217.4 \\
\hline T6-N250+T1 & 5333 & 4750 & 87.3 & 80.4 & 229.2 & 203.5 \\
\hline $\mathrm{T} 7-\mathrm{N} 300+\mathrm{T} 1$ & 5416 & 4917 & 85.2 & 81.7 & 217.4 & 209.1 \\
\hline SE & 468 & 101 & 3.5 & 5.8 & 8.0 & 12.3 \\
\hline $\operatorname{LSD}(0.05)$ & 1298 & 303 & 10.3 & 16.0 & 22.6 & 36.1 \\
\hline
\end{tabular}


Shelling percentage was not affected significantly with the application of fertilizer (Table 4). The application of $\mathrm{N}$ fertilizer with basal amounts of $\mathrm{P}$ and $\mathrm{K}$ resulted to increase in 1000-grain weight over the absolute control, but statistical analysis has shown that the increase was not significant (Table 4). On the contrary, it was observed [4] that 1000 -grain weight of maize increased significantly with the increase levels of $\mathrm{N}$.

\subsection{Grain and Stover Yield}

Result of grains and stover yield presented in table 5 indicated that there was significant increase in grain yield due to $\mathrm{N}$ application over no $\mathrm{N}$ application as well as over the absolute control. The increase in grain yield was significant only up to $100 \mathrm{KgN} /$ ha in both 1992 and 1993, beyond this level of N, the increase in yield of grain was no significant. Similarity, the application of N fertilizer increased stover yield significantly up to $50 \mathrm{KgN} / \mathrm{ha}$ in 1992 and $150 \mathrm{KgN} / \mathrm{ha}$ in 1993. However, [9] Subhan (1997) reported a significant stover yield increase with the application of $300 \mathrm{KgN} / \mathrm{ha}$. The result of this study therefore indicated that $\mathrm{N}$ fertilizer application is necessary if maize is grown for grain or stover, and that maximum grain yield of maize could be obtained at $100 \mathrm{KgN} / \mathrm{ha}$ in the semi- arid region of Nigeria. It is worthwhile to mentioned that $\mathrm{N}$ fertilizer recommendation for maize production in the savanna zone of Nigeria was $100 \mathrm{KgN} / \mathrm{ha}$ [10] (IAR, 1983), but there has been reports that sole maize crop will respond significantly up to 120-150 $\mathrm{KgN} / \mathrm{ha}$ in Northern Nigeria [3].

Table 5 Effect of N on Grain and Stover Yield of Maize during 1992 and 1993 Cropping Seasons

\begin{tabular}{lcccc}
\hline Treatment & \multicolumn{2}{c}{ Grain Yield (Kg/ha) } & \multicolumn{2}{c}{ Stover Yield (Kg/ha) } \\
(Kg/ha) & $\mathbf{1 9 9 2}$ & $\mathbf{1 9 9 3}$ & $\mathbf{1 9 9 2}$ & $\mathbf{1 9 9 3}$ \\
\hline $\begin{array}{l}\text { To-Absolute Control } \\
\text { (no N,P and K) }\end{array}$ & 1455 & 750 & 3750 & 2917 \\
T1-Control & & & & \\
(only P and K) & 1483 & 1833 & 4583 & 4583 \\
T2-N50+T1 & & & & \\
T3-N100+T1 & 2383 & 2417 & 6417 & 5416 \\
T4-N150+T1 & 3592 & 3583 & 7500 & 6017 \\
T5-N200+T1 & 3975 & 3600 & 7139 & 6119 \\
T6-N250+T1 & 4208 & 3983 & 7083 & 6250 \\
T7-N300+T1 & 4692 & 3833 & 7000 & 6250 \\
SE & 4608 & 4000 & 6667 & 5667 \\
LSD(0.05) & 570 & 347 & 620 & 440 \\
\hline & 1580 & 1123 & 1719 & 1220 \\
\hline
\end{tabular}

\subsection{Nitrogen Uptake by Grain and Stover of Maize}

Data on $\mathrm{N}$ percent in grain and Stover and total $\mathrm{N}$ uptake is presented in Table 6. Statistical analysis of the data indicated that there was significant increase in grain $\mathrm{N}$ with the application of $\mathrm{N}$ up to $150 \mathrm{KgN} / \mathrm{ha}$ when compared with the no $\mathrm{N}$ application. The result of this study supports the result of the experiments of [11] Rhoads and Stanley (1981) who reported that $\mathrm{N}$ concentration in grains tended to increase with increases in rates of $\mathrm{N}$ application. The result of this experiment also agreed with the reports of [12] Thiraporn et al, (1992) who stated that grain $\mathrm{N}$ increased in response to $\mathrm{N}$ fertilization up to $160 \mathrm{KgN} / \mathrm{ha}$.

The result this study has shown that application of $\mathrm{N}$ fertilizer did not increased significantly the $\mathrm{N}$ content of Maize Stover (Table 6). The study also indicated that about one-third of $\mathrm{N}$ was present in the stover whereas the remaining two-third was present in the grain. Earlier reports of [13] Singh and Balasubramanian (1983) revealed that about $25 \% \mathrm{~N}$ was present in the stover, $50 \%$ in the grain and the remaining $25 \%$ in the root system.

The study has therefore revealed that any time chemical fertilizer is applied to the soil some quantity is removed from the soil by plant roots and translocated to the plant for vegetative growth and grain formation. From this study, onethird of $\mathrm{N}$ was removed from the soil and stored in the Stover, and about two-third of N was stored in the grain. This means that more $\mathrm{N}$ is needed in grain formation than in vegetative growth phase of maize. Moreover, since $\mathrm{N}$ uptake by maize has revealed that certain quantity of $\mathrm{N}$ is found in the Stover, the return of this Stover to the soil during land preparation means the return of $\mathrm{N}$ to the soil from the Stover after its mineralization. 
Kaltungo et al. / World Journal of Advanced Research and Reviews, 2020, 05(02), 080-086

Table 6 Effect of N on percent N content in Grain and Stover of maize and total uptake (kg/ha) during 1993 growing seasons

\begin{tabular}{|c|c|c|c|c|c|}
\hline \multirow{2}{*}{$\begin{array}{l}\text { Treatment } \\
\text { (Kg/ha) }\end{array}$} & \multicolumn{2}{|c|}{ Percent N } & \multicolumn{2}{|c|}{ N Uptake(Kg/ha) } & \multirow{2}{*}{$\begin{array}{l}\text { Total N uptake(Kg/ha) } \\
\text { (grain + stover) }\end{array}$} \\
\hline & Grain & Stover & Grain & Stover & \\
\hline $\begin{array}{l}\text { To-Absolute Control } \\
\text { (no N,P and K) }\end{array}$ & 0.61 & 0.47 & 4.6 & 13.7 & 18.3 \\
\hline $\begin{array}{l}\text { T1- Control } \\
\text { (only P and K) }\end{array}$ & 1.60 & 0.58 & 29.3 & 26.6 & 55.9 \\
\hline T2-N50+T1 & 1.66 & 0.49 & 40.1 & 26.5 & 66.6 \\
\hline T3-N100+T1 & 1.70 & 0.56 & 60.9 & 31.3 & 92.2 \\
\hline $\mathrm{T} 4-\mathrm{N} 150+\mathrm{T} 1$ & 1.81 & 0.58 & 65.2 & 34.9 & 100.1 \\
\hline $\mathrm{T} 5-\mathrm{N} 200+\mathrm{T} 1$ & 1.63 & 0.58 & 65.0 & 36.3 & 101.3 \\
\hline T6-N250+T1 & 1.65 & 0.53 & 63.2 & 33.1 & 96.3 \\
\hline T7-N300+T1 & 1.35 & 0.51 & 59.0 & 28.9 & 82.9 \\
\hline SE & 0.04 & 0.06 & 4.6 & 5.6 & 6.7 \\
\hline $\operatorname{LSD}(0.05)$ & 0.13 & 0.17 & 22.5 & 14.2 & 35.4 \\
\hline
\end{tabular}

\section{Conclusion}

The use of nitrogen fertilizer application for optimum yields of maize in the savanna zone of Nigeria has become necessary because the continuous cropping system practice in the savanna has rendered the soil less productive when no fertilizers are applied. Previous study on $\mathrm{N}$ nutrition of maize in the savanna zone of Nigeria had reported that maize requires about $120-150 \mathrm{KgN} /$ ha but with the release of improved verities of maize particularly TZESR-W, it has become pertinent to work out its $\mathrm{N}$ requirement in the semi-arid region of Nigeria. The result of this investigation therefore revealed that the maize crop, TZESR-W, responded to $\mathrm{N}$ fertilizer application up to $100 \mathrm{Kg} \mathrm{N} / \mathrm{ha}$ resulting in significant increase in maize plant height (at all stages of sampling), cob length, cob girt, grain yield and dry cob weight (after harvest) when compared with the absolute control in both 1992 and 1993. Furthermore, stover yield of maize and nutrient concentration in grain were also significantly affected by $\mathrm{N}$ application. In conclusion, this study revealed that $\mathrm{N}$ fertilization is imperative for maize cultivation in the semi- arid region. Thus, any maize cultivation that does not include the application of $\mathrm{N}$ would result to a decrease in vegetative growth and subsequently the final yield of maize grain and stover.

\section{Compliance with ethical standards}

\section{Acknowledgments}

Authors are thankful to the officials of National Fertilizer Testing Programmes for financial assistance during the course of this study.

\section{Disclosure of conflict of interest}

There is no conflict of interest among the authors.

\section{References}

[1] Kaltungo JH. (1995). Effect of different rates of NPK fertilizer on growth, yield and nutrient uptake of maize (TZESR-W) (Zea mays L.). M.Sc dissertations. Abubakar Tafawa Balewa University Bauchi, Nigeria, 85-90.

[2] Balasubramain V, Nnadi LA and Mokwunye AU. (1978). Fertilizing sole crop maize for high yields. Samaru Miscellaneous Paper76. Institute for Agricultural Research, Ahmadu Bello University, Zaria, Nigeria, 50-55. 
[3] Ologunde 00. (1981). Efficient use of fertilizers: Effect of placement, method and time of application on grain yield of maize in the savanna zones of Northern Nigeria. Paper Presented at First National Seminar on the Green Revolution in Nigeria. Institute for Agricultural Research, Ahmadu Bello University, Zaria, Nigeria, 10-12.

[4] El- Sharkaway MA, Sagir K, Sorour FA and Youef ME. (1976). Investigations on maize in the Libyan Arabs Republic. I. Effect of plant spacing and nitrogen level on growth and yield of maize. Libyan Journal of Agriculture, 5, 1-8.

[5] Adetiloye BO, Okigbo BN and Ezedima FOC. (1984). Responses by maize plant and ear shoot characters to growth factors in southern Nigeria. Field Crops Research, 9, 265-277.

[6] Nimje PM and Seth J. (1988). Effect of Nitrogen on growth, yield and quality of winter maize. Indian Journal of Agronomy, 33(2), 209-211.

[7] Bataev Ya V and Magomeadov Sh M. (1991). Effect of mineral fertilizer on maize. Field Crops Abstracts, 45(4), 256.

[8] Gagro M. (1977). Effect of nitrogen and plant population on stem diameter and proportion of lodged plants in maize hybrids BcSK 39-41 and OsSK 218. Field Crops Abstracts, 32(2), 101.

[9] Subhan V. (1987). Effect of nitrogen fertilizer on vegetative growth and yield of maize (Zea mays L.). Soils and Fertilizers, 53(3), 428-527.

[10] IAR. (1983). Notes on Cereals Improvement Programme. Cropping Scheme Meeting. Institute for Agricultural Research, Ahmadu Bello University. Zaria, Nigeria, 30-39.

[11] Rhoads FM and Stanley RL. (1981). Fertilizer scheduling, yield and nutrient uptake of irrigated corn. Agronomy Journal, 73, 971-974.

[12] Thiraporn R, Feil B and Stamp P. (1992). Effect of nitrogen fertilization on grain yield and accumulation of N, P and $\mathrm{K}$ in the grains of tropical maize. Journal of Agronomy and Crop Science, 169, 9-16.

[13] Singh L and Balasubramanian V. (1983). Direct and residual effect of P and K on crop yields, nutrient uptake and soil properties at Kadawa, Nigeria. Fertilizer Agriculture, 84, 102-110.

\section{How to cite this article}

Kaltungo JH, Voncir N and Singh L. (2020). Growth and yield response of streak virus resistant maize (TZESR-W) to different nitrogen rates on a sandy loam soil of semi-arid region of Nigeria. World Journal of Advanced Research and Reviews, 5(2), 80-86. 